DOI: $10.15193 /$ zntj/2019/120/296

\author{
ELŻBIETA ROSIAK, DANUTA KOŁOŻYN-KRAJEWSKA, ANTONI GORYL, \\ MAŁGORZATA JAŁOSIŃSKA, KATARZYNA KAJAK-SIEMASZKO, \\ MONIKA TRZĄSKOWSKA, DOROTA ZIELIŃSKA, ILONA TWARDOWSKA, \\ STEFAN RUTKOWSKI, MATEUSZ GEMBA
}

\title{
SZACOWANIE WZROSTU I PRZEŻYWALNOŚCI BAKTERII PROBIOTYCZNYCH, PSUJĄCYCH I PATOGENNYCH W ŻYWNOŚCI Z WYKORZYSTANIEM PROGNOSTYCZNEJ BAZY DANYCH (ProgBaz SGGW)
}

\author{
Streszczenie
}

Prognozowanie mikrobiologiczne polega na założeniu powtarzalności odpowiedzi populacji drobnoustrojów na zadane czynniki środowiska produktu żywnościowego. Na podstawie danych empirycznych pochodzących z doświadczeń mikrobiologicznych opracowywane są modele prognostyczne jako programy komputerowe bądź bazy danych dostępne on-line.

Celem pracy było utworzenie bazy danych modeli prognostycznych bakterii potencjalnie probiotycznych, saprofitycznych i patogennych w formie użytecznego dla odbiorcy końcowego narzędzia zainstalowanego na serwerze SGGW pod nazwą ProgBaz SGGW. Materiał do badań stanowiły matematyczne modele wzrostu i przeżywalności bakterii saprofitycznych (psychrotrofów, Pseudomonas spp., drożdzy i pleśni) i patogennych: Salmonella spp., Staphylococcus aureus, Listeria monocytogenes (mikroflory niekorzystnej) oraz potencjalnie probiotycznych szczepów z rodzaju Lactobacillus (mikroflory korzystnej). Modele opracowano w Zakładzie Higieny i Zarządzania Jakością Żywności Wydziału Nauk o Żywieniu Człowieka i Konsumpcji SGGW w Warszawie, w latach 1997 - 2008.

ProgBaz jest dostępny na stronie głównej SGGW w Warszawie w zakładce Gospodarka oraz na stronie Wydziału Nauk o Żywieniu Człowieka i Konsumpcji SGGW w zakładce Nauka i Usługi. Użytkownik może dokonać oszacowania wzrostu lub przeżywalności drobnoustrojów w czasie pod wpływem czynników środowiskowych (temperatury, poziomu $\mathrm{NaCl}$, poziomu $\mathrm{NaNO}_{2}$, dodatku inuliny) w następujących produktach: modelowym produkcie z mięsa rozdrobnionego, produktach rynkowych mlecznych, mięsnych i warzywnych. Oprócz prognozy wzrostu możliwe jest uzyskanie informacji na temat cech populacji $(\lambda, \mu$,

Dr inż. E. Rosiak, prof. dr hab. D. Kołożyn-Krajewska, dr M. Jałosińska, dr inż. K. Kajak-Siemaszko, dr hab. inż. M. Trzaskowska, dr inż. D. Zielińska, mgr inż. M. Gemba, Katedra Technologii Gastronomicznej i Higieny Żywności, Wydz. Nauk o Żywieniu Człowieka i Konsumpcji, Szkoła Główna Gospodarstwa Wiejskiego w Warszawie, ul. Nowoursynowska 159 C, 02-776 Warszawa, dr A. Goryl, Katedra Ekonometrii i Badań Operacyjnych, Wydz. Zarzadzania, Uniwersytet Ekonomiczny w Krakowie, ul. Rakowicka 27, 31-510 Kraków, I. Twardowska, S. Rutkowski, Ustugi Informatyczne, Warszawa.

Kontakt: elzbieta_rosiak@sggw.pl 
GT, N) oraz w przypadku modelu walidowanego - jakości prognoz. Są to informacje pozwalające oszacować bezpieczeństwo produktu oraz jego termin przydatności do spożycia. ProgBaz może być stosowany do oceny ryzyka mikrobiologicznego żywności, opracowywania planów bezpieczeństwa żywności, ograniczania marnotrawstwa żywności, projektowania nowych produktów oraz stanowić narzędzie edukacyjne i szkoleniowe.

Słowa kluczowe: żywność, prognozowanie mikrobiologiczne, modele prognostyczne, prognostyczne bazy danych, ProgBaz

\section{Wprowadzenie}

Mikrobiologia prognostyczna żywności to subdyscyplina mikrobiologii pozwalająca na matematyczny opis zachowania populacji mikroorganizmów występujących w żywności [15]. Umożliwia przewidywanie wzrostu, przeżywalności lub inaktywacji mikroorganizmów. Podstawowym założeniem mikrobiologii prognostycznej jest powtarzalność zachowań mikroorganizmów obecnych w żywności oraz możliwość opisania ich za pomocą zależności matematycznych nazywanych modelami matematycznymi $[8,18]$.

Właściwości i użyteczność modeli znalazły odzwierciedlenie w prawie żywnościowym Unii Europejskiej. W Rozporządzeniu Komisji (WE) nr 2073/2005 z dnia 15 listopada 2005 r. z późniejszymi zmianami w sprawie kryteriów mikrobiologicznych dotyczacych środków spożywczych zaleca się, aby w czasie ustalania terminu przydatności do spożycia wykorzystywać modele prognostyczne dotyczące bakterii wskaźnikowych, uwzględniając krytyczne czynniki wzrostu lub przeżywalności drobnoustrojów $[15,16]$. Matematyczne modele prognostyczne dostarczają wyników wielokrotnie szybciej niż challenge tests, które polegają na szacowaniu okresu trwałości produktu spożywczego w tych samych warunkach, jakie panują podczas procesu dystrybucji czy przechowywania żywności, na podstawie liczby drobnoustrojów wyznaczających poziom akceptowalny lub poziom zepsucia [1].

Pionierskim programem dostępnym od lat 90 . XX wieku, umożliwiającym prognozowanie wzrostu i inaktywacji termicznej/nietermicznej bakterii patogennych jest Pathogen Modeling Program (PMP). PMP opracowany został przez dwa Departamenty Rolnictwa Stanów Zjednoczonych (USDA): Agricultural Research Service (ARS) i Eastern Regional Research Center (ERRC) [2, 3, 6, 7]. Innymi programami wykorzystywanymi w mikrobiologii prognostycznej są: GroPIN, FISHMAP, FSSP, Sym'Previus, Listeria Meat Model, Dairy Product Safety Predictor. Programy te opracowano dla wybranych szczepów bakterii w konkretnych matrycach żywnościowych. Programy FDA-iRISK i TRiMiCri wykorzystywane są w ocenie ryzyka, natomiast program Microbiol Responses Viewer oszacowuje typ wzrostu drobnoustrojów lub jego brak w różnych matrycach żywnościowych [14, 17]. Programy GlnaFiT, FILTREX, PMM-Lab opracowano w celu generowania mikrobiologicznych modeli 
prognostycznych [15]. Programy te stanowią samodzielne narzędzia prognozowania mikrobiologicznego.

W sieci Internet dostępne są: baza ComBase zbierająca publikowane i niepublikowane modele prognostyczne [13] oraz Basaline i MicroHibro opracowane w latach 2011 - 2012, które umożliwiają tworzenie modeli zdefiniowanych przez użytkownika do szacowania wzrostu/inaktywacji drobnoustrojów w żywności [5, 15].

Celem pracy było utworzenie bazy danych modeli prognostycznych bakterii potencjalnie probiotycznych, saprofitycznych i patogennych w formie użytecznego dla odbiorcy końcowego narzędzia zainstalowanego na serwerze SGGW pod nazwą ProgBaz SGGW.

\section{Material i metody badań}

Materiał do badań stanowiły matematyczne modele wzrostu i przeżywalności bakterii saprofitycznych i patogennych oraz potencjalnie probiotycznych. Modele opracowane zostały w wyniku badań własnych, prowadzonych w Zakładzie Higieny i Zarządzania Jakością Żywności Wydziału Nauk o Żywieniu Człowieka i Konsumpcji SGGW w Warszawie, w latach 1997 - 2008, we współpracy z Uniwersytetem Ekonomicznym w Krakowie. Modele zostały opracowane jako element prac doktorskich Małgorzaty Jałosińskiej [9], Elżbiety Kopeć [12], Katarzyny Kajak [10], Moniki Trząskowskiej [19], Doroty Zielińskiej [20] pod kierunkiem promotorskim prof. dr hab. Danuty Kołożyn-Krajewskiej we współpracy z dr. Antonim Gorylem. Modele opracowane w przypadku produktów kontaminowanych bakteriami patogennymi opracowano w wyniku projektu rozwojowego NR12009706/2009. Modele matematyczne weryfikujące skonstruowane wcześniej modele opracowane w przypadku modelowego produktu $\mathrm{z}$ mięsa rozdrobnionego opracowano jako wynik dwóch prac magisterskich $[4,11]$, natomiast modele weryfikujące modele opracowane w przypadku produktów kontaminowanych bakteriami patogennymi opracowano w wyniku realizacji projektu Inkubator Przedsiębiorczości 11/II+/2017.

W opracowaniu ProgBaz SGGW wykorzystano trzy- lub czteroparametrowe funkcje Gompertza i logistyczną, inne funkcje nieliniowe oraz funkcje wielomianowe (drugiego i trzeciego stopnia). Do weryfikacji modeli zastosowano następujące parametry matematyczno-statystyczne:

- $\mathrm{R}^{2}$ - współczynnik determinacji (współczynnik regresji - $\mathrm{R}^{2}$ ) używany jako ogólna miara dopasowania oszacowanego modelu do danych empirycznych. Współczynnik determinacji jest miarą siły liniowego związku między danymi:

- $\mathrm{R}^{2}=1$ - dane leżą dokładnie na "płaszczyźnie" regresji (zmienność jest wyjaśniona W $100 \%$;

$-\mathrm{R}^{2}=0$ - regresja niczego nie wyjaśnia, dane są nieskorelowane; 
$-0<\mathrm{R}^{2}<1$ - dopasowanie modelu jest tym lepsze, im wartość współczynnika determinacji jest bliższa jedności;

- MSE - (ang. Mean Squared Error) błąd średniokwadratowy jest wartością kwadratu błędu, czyli różnicy pomiędzy estymatorem a wartością estymowaną;

- Af - (ang. accuracy factor) czynnik dokładności jest miarą skuteczności prognoz modelu oraz informuje o stopniu dopasowania modelu do krzywej wzrostu/przeżywalności mikroorganizmów, osiąga maksymalną wartość 1;

- Bf - (ang. bias factor) czynnik skłonności/nachylenia informuje o ile średnio wartości obserwowane różnią się od przewidywanych:

- $\mathrm{Bf}<1$ oznacza, że wartości obserwowane są większe od przewidywanych;

- $\mathrm{Bf}>1$ oznacza, że wartości obserwowane są mniejsze od przewidywanych.

W ramach zrealizowanego projektu Inkubator Innowacyjności+ wyłoniono, w postępowaniu ofertowym, firmę informatyczną Usługi Informatyczne i poddano wizualizacji opracowania matematyczne znajdujące się w plikach MS Excel. Ponadto wykonano i podpięto interfejs zgodny z interfejsem obecnej strony SGGW, opracowano filtrowanie danych i dodano funkcjonalność zmiany istniejących wybranych parametrów wejściowych funkcji oraz stworzono panel użytkownika i administratora. Ostatecznie opracowano bazę $\mathrm{w}$ postaci pliku gotowego do umieszczenia na serwerze SGGW w Warszawie w technologii i zasadach Open Source (PHP, jQuery, JavaScript, CSS). W najbliższym czasie zostanie dodana opcja administratora ProgBaz pozwalająca na rejestrowanie liczby użytkowników.

\section{Wyniki i dyskusja}

Korzystanie z opracowań ProgBaz SGGW (v. 1.0) jest możliwe na zasadach bezpłatnego dostępu ze strony głównej SGGW w Warszawie, w zakładce Gospodarka www.prognostycznabazadanych.sggw.pl oraz na stronie Wydziału Nauk o Żywieniu Człowieka i Konsumpcji SGGW w Warszawie w zakładce Usługi - www.wnzck. sggw.pl/uslugi/prognostyczna-baza-danych i Nauka - www.wnzck.sggw.pl/nauka/ prognostyczna-baza-danych.

W belce górnej (fot. 1) widoczne są zakładki odzwierciedlające Layout strony głównej SGGW oraz znajdujący się w lewym górnym rogu link do strony Wydziału Nauk o Żywieniu Człowieka i Konsumpcji SGGW. Po wejściu na podane wyżej strony uwidaczniają się, z lewej strony, zakładki Prognostycznej Bazy Danych (fot. 1). W zakładkach O NAS, ZESPÓŁ PROGBAZ, REGULAMIN, PUBLIKACJE i KONTAKT użytkownik znajdzie odpowiednio informacje dotyczące możliwości wykorzystania bazy, informacje o autorach bazy modeli prognostycznych, regulaminie dostępu i korzystania z bazy, 11 linków do publikacji pracowników Zakładu Higieny i Zarządzania Bezpieczeństwem Żywności, dotyczących matematycznego prognozo- 
wania w mikrobiologii żywości oraz dane teleadresowe osoby do kontaktu w sprawach dotyczących ProgBaz.

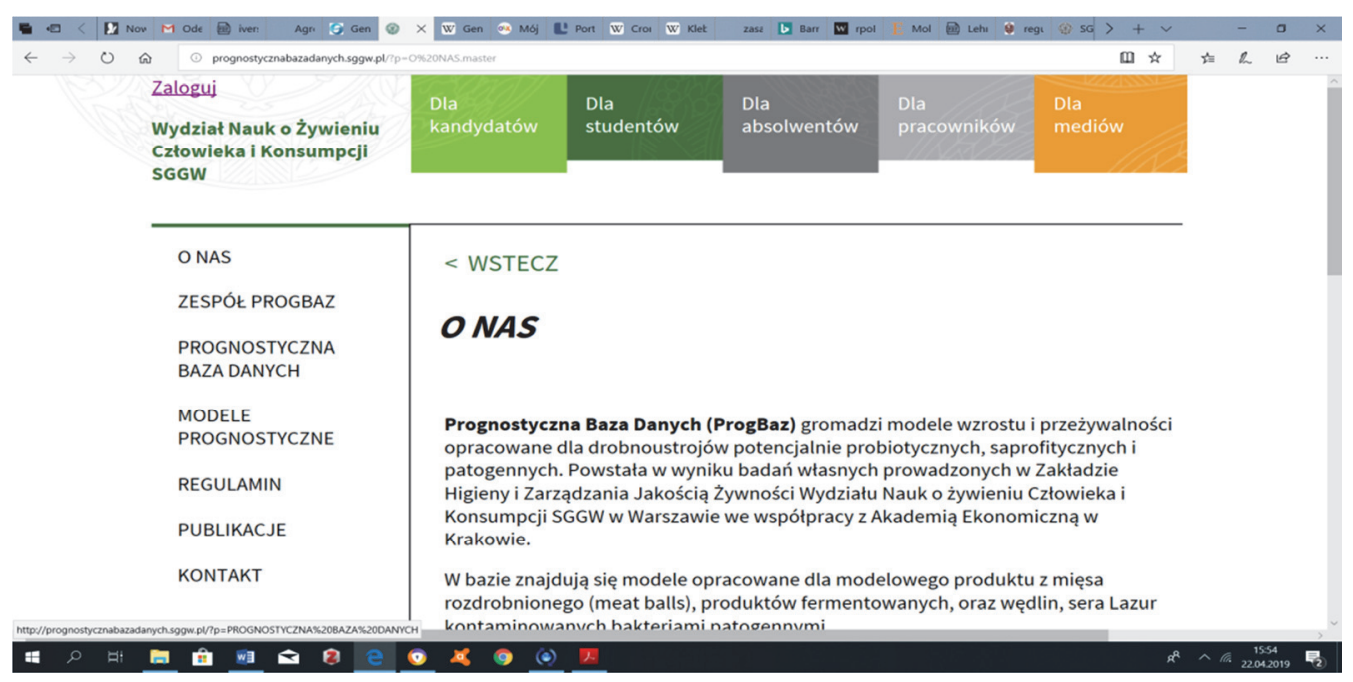

Fot. 1. Print Screen okna z ProgBaz SGGW

Photo 1. Print Screen of the window with ProgBaz SGGW

Wejście do bazy modeli prognostycznych odbywa się na dwa sposoby. Pierwszy polega na wyborze mikroflory: korzystnej lub niekorzystnej, które znajdują się w zakładce PROGNOSTYCZNA BAZA DANYCH (rys. 1). Można też dostać się do bazy modeli prognostycznych poprzez wybór modelu w zakładce MODELE PROGNOSTYCZNE. Do wyboru są modele opracowane w przypadku modelowego produktu $\mathrm{z}$ mięsa rozdrobnionego oraz modele opracowane w przypadku konkretnych produktów rynkowych: kiełbasy dojrzewającej, kiełbasy parzonej drobno rozdrobnionej, pasztetu wieprzowego i sera probiotycznego z przerostem pleśniowym, które kontaminowano znaną koncentracją bakterii patogennych: Staphylococcus aureus, Listeria monocytogenes, Salmonella Enteritidis. Ostania grupa to modele dotyczące mięsa rozdrobnionego zweryfikowane w żywności na przykładzie befsztyka wołowego, kotleta mielonego, kotleta wieprzowo-wołowego, kotleta wołowego z pieczarką, pulpeta wołowo-wieprzowego, sosu bolognese. Ta grupa modeli będzie w kolejnych wersjach ProgBaz rozwijana i uzupełniana.

W ProgBaz znajdują się modele opisujące wzrost i przeżywalność mikroflory korzystnej, potencjalnie probiotycznej, występującej w fermentowanym napoju sojowym i w fermentowanym soku marchwiowym. W przypadku fermentowanego napoju sojowego po wyborze temperatury przechowywania w zakresie $5 \div 20{ }^{\circ} \mathrm{C}$ można wybrać dwa modele A lub B różniące się rodzajem funkcji matematycznej użytej do opisu 
danych otrzymanych z eksperymentu. Eksperyment polegał na ocenie przeżywalności szczepu Lactobacillus casei $\mathrm{KN} 291$ [ $\log \mathrm{jtk} / \mathrm{ml}$ ] w napoju sojowym podczas przechowywania w temp.: $5,10,15,20^{\circ} \mathrm{C}$ w ciągu 29 dni. Prognoza liczby drobnoustrojów jest możliwa w zakresie $0 \div 62$ dni i w temp.: $5 \div 25^{\circ} \mathrm{C}$.

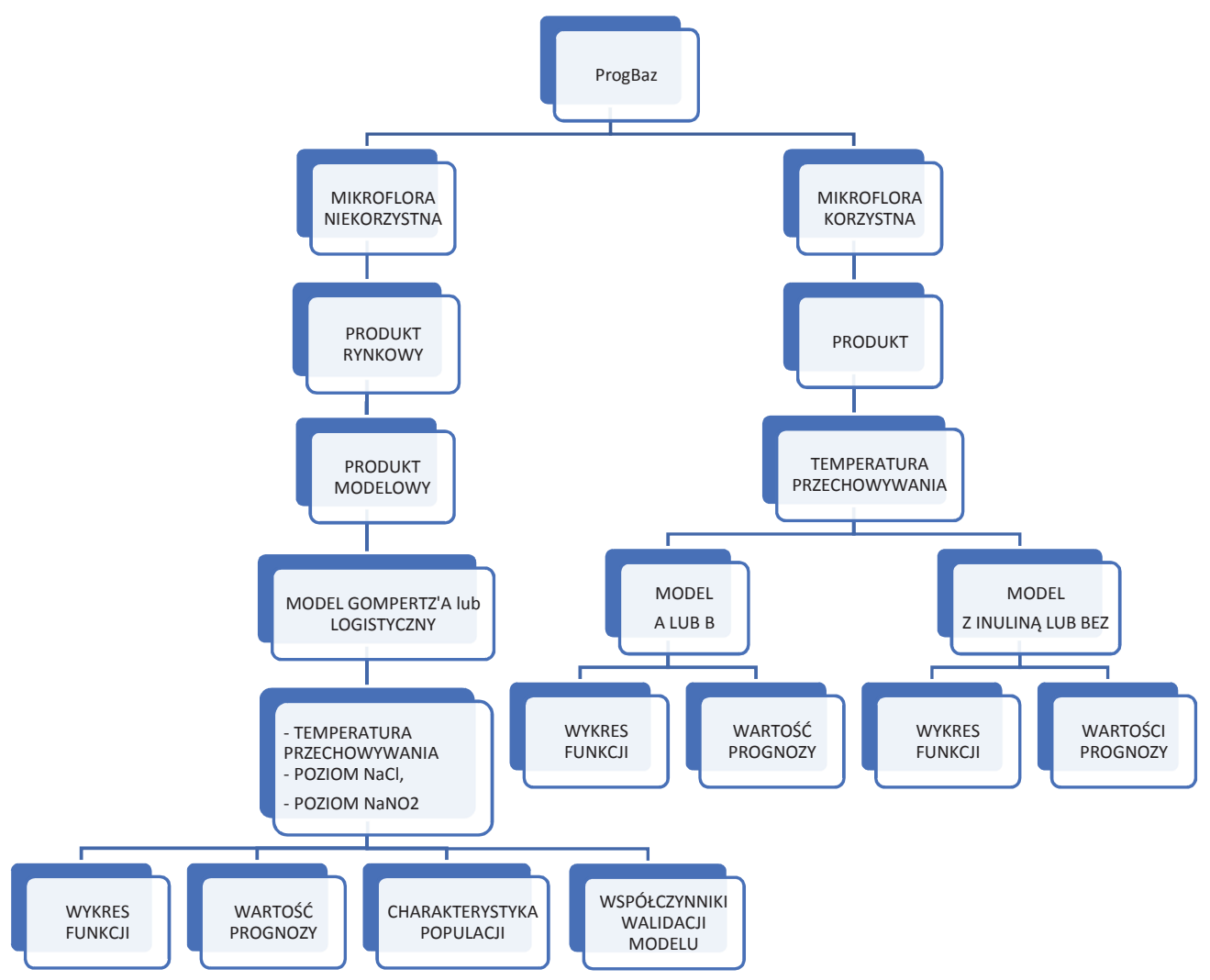

Rys. 1. Schemat korzystania z modeli prognostycznych w ProgBaz SGGW

Fig. 1. Diagram showing how to use predictive models in ProgBaz SGGW

W przypadku fermentowanego soku marchwiowego eksperyment prowadzono w temp.: 5, 10 i $15^{\circ} \mathrm{C}$, analizy wykonywano co 4 dni w ciągu $0 \div 32$ dni w każdej z ww. temperatur. Opracowano model wzrostu i przeżywalności Lactobacillus acidophilus $\mathrm{CH}-2 \mathrm{w}$ soku marchwiowym (z dodatkiem i bez dodatku inuliny) w temp.: $0 \div 20^{\circ} \mathrm{C}$ i w ciągu $0 \div 36$ dni przechowywania (fot. 2 ). 


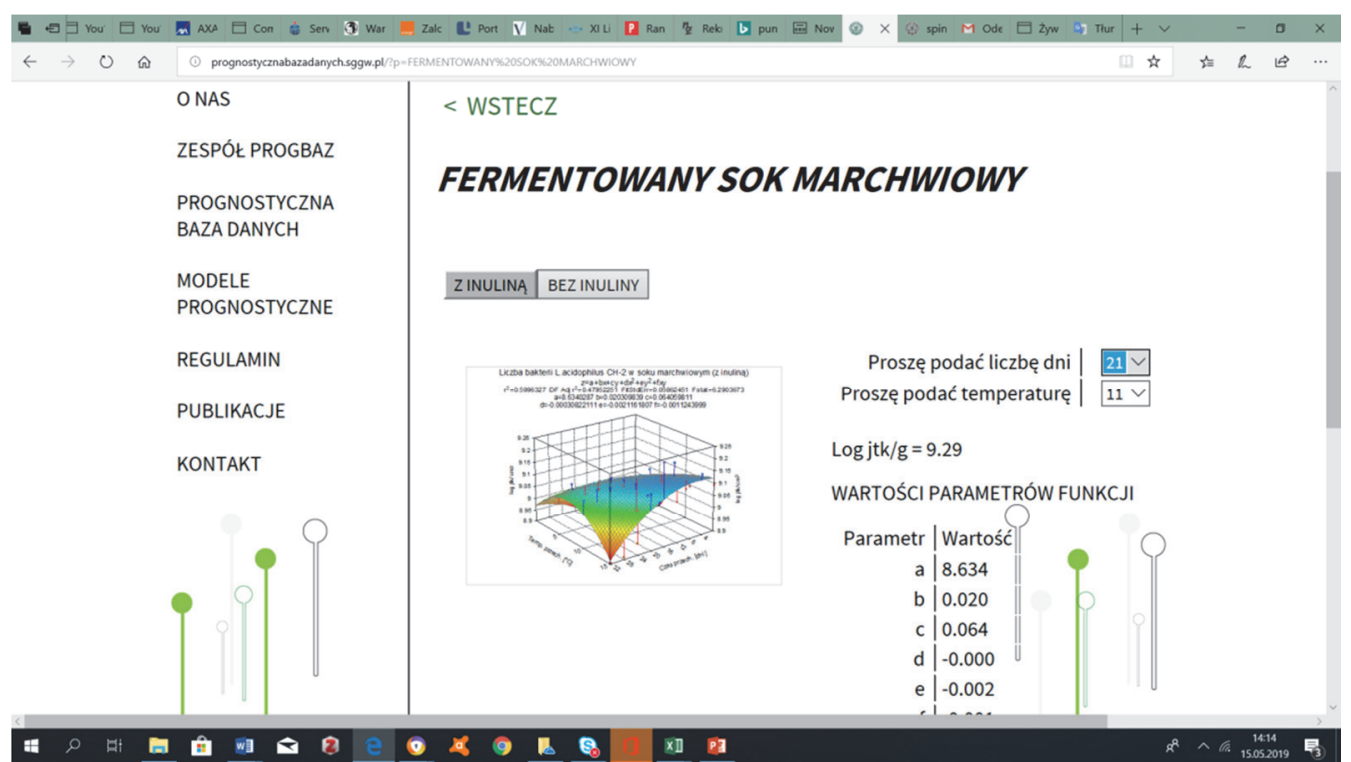

Fot. 2. Prognoza wzrostu L. acidophilus $\mathrm{CH}-2[\log 9,29 \mathrm{jtk} / \mathrm{ml}]$ w temp. $11{ }^{\circ} \mathrm{C}$ po 21 dniach przechowywania soku marchwiowego $\mathrm{z}$ dodatkiem inuliny

Photo 2. Predicting growth of L. acidophilus CH-2 $[\log 9.29 \mathrm{jtk} / \mathrm{ml}]$ at $11{ }^{\circ} \mathrm{C}$ after 21 day storage of carrot juice with inulin additive

Dostępny model wykorzystuje powierzchnię odpowiedzi opracowaną z zastosowaniem funkcji wielomianowej Gompertza i logistycznej.

ProgBaz zawiera także modele matematyczne opracowane w przypadku mikroflory saprofitycznej i patogennej: Pseudomonas spp., psychrotrofów, drożdży i grzybów pleśniowych oraz Salmonella spp., Listeria monocytogenes, Staphylococcus aureus (produkty kontaminowane). Po wyborze produktu i grupy drobnoustrojów należy wybrać temperaturę przechowywania i/lub inne czynniki determinujące wzrost mikroflory (poziom soli, poziom azotanu sodu). Na podstawie obliczeń matematycznych z zastosowaniem odpowiedniej funkcji matematycznej (widocznej najczęściej na wykresie), zostaną wyświetlone właściwości populacji drobnoustrojów wyrażone jako: długość trwania lag fazy, maksymalne tempo wzrostu w fazie wykładniczej, czas pomiędzy podziałami drobnoustrojów oraz maksymalna gęstość populacji (fot. 3).

Dzięki zastosowaniu powierzchni odpowiedzi możliwe jest uzyskanie ekstrapolowanej liczby drobnoustrojów (poza obszarem danych pochodzących z eksperymen$\mathrm{tu}$ ), natomiast w przypadku modelu opracowanego dla produktu $\mathrm{z}$ mięsa rozdrobnionego zweryfikowanego w żywności na przykładzie befsztyka wołowego, kotleta mielonego, kotleta wieprzowo-wołowego, kotleta wołowego z pieczarką, pulpeta wołowo-wieprzowego, sosu bolognese dostępne są parametry matematyczno-statystyczne ( $\mathrm{R}^{2}$, MSE, Af, Bf) świadczące o jakości prognoz generowanych przez model (fot. 4). 


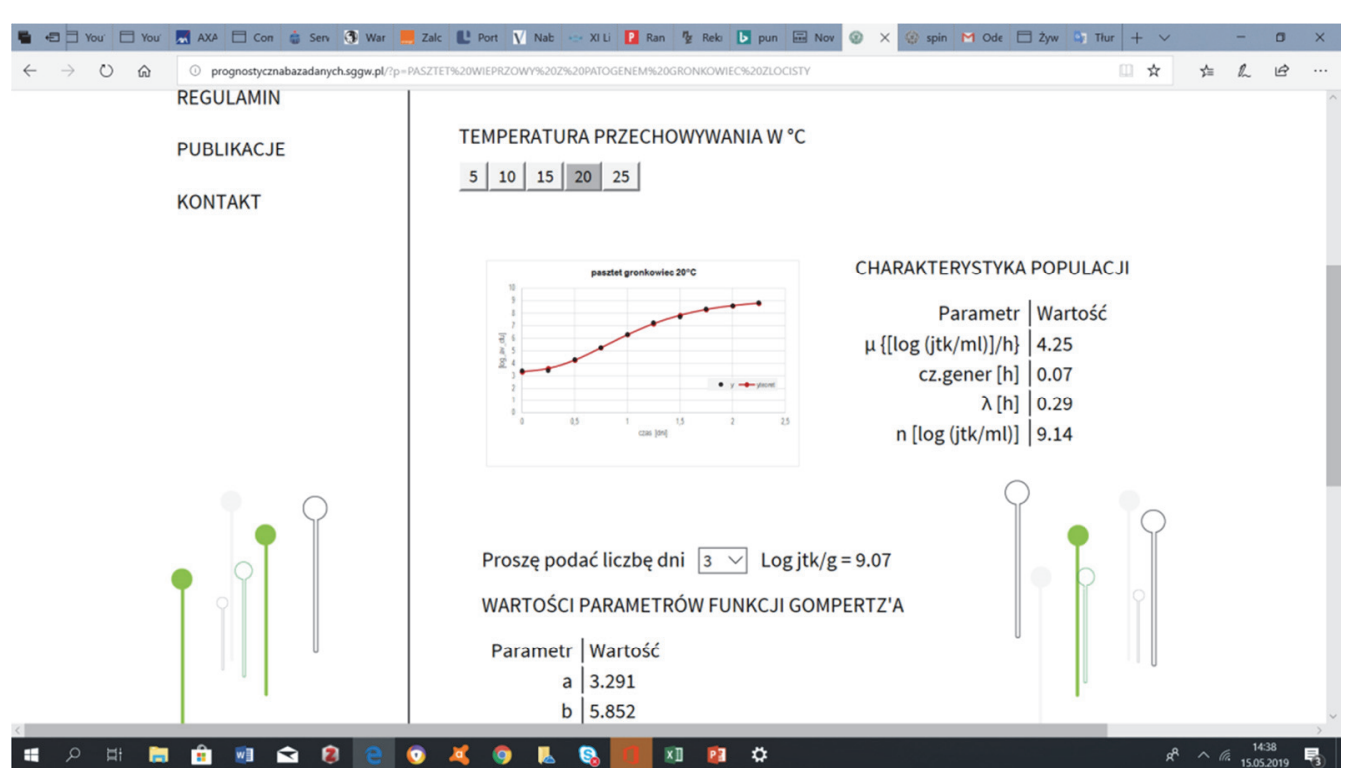

Fot. 3. Prognoza wzrostu gronkowca złocistego (S. aureus) w pasztecie w temp. $20^{\circ} \mathrm{C}$ po trzech dniach przechowywania

Photo 3. Predicting growth of Staphylococcus aureus in pâté at $20^{\circ} \mathrm{C}$ after 3 day storage

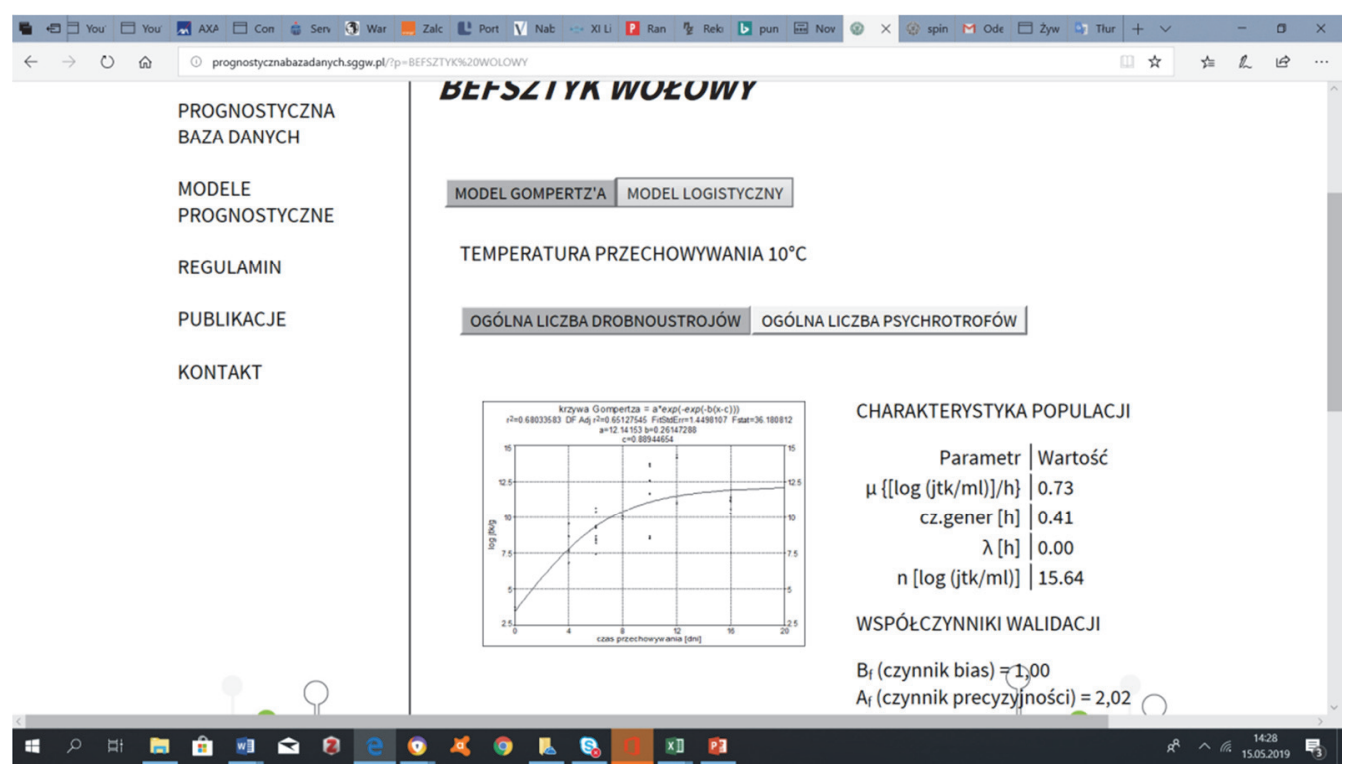

Fot. 4. Walidacja modelu opracowanego w przypadku produktu z mięsa rozdrobnionego na przykładzie befsztyka wołowego przechowywanego w temp. $10^{\circ} \mathrm{C}$

Photo 4. Validation of model developed in the case of minced meat and exemplified by beefsteak stored at $10{ }^{\circ} \mathrm{C}$ 
Rozwój ProgBaz będzie zależał od nawiązania współpracy z innymi ośrodkami naukowymi, które dysponują opublikowanymi danymi, pozwalającymi na opracowanie modeli matematycznych lub opublikowane modele gotowe do umieszczenia w ProgBaz z odpowiednią afiliacją instytucji i twórców.

Kolejną grupą modeli, która jest opracowywana i zostanie dodana do ProgBaz SGGW są modele produktu z mięsa rozdrobnionego z wykorzystaniem Sieci Neuronowych. Niezbędna jest także systematyczna walidacja opracowanych modeli prognostycznych. Walidacja modelu prognostycznego jest ostatnim etapem w procesie tworzenia modelu matematycznego. Modele zwalidowane pozwalają na ocenę zachowania się modeli w nowych warunkach i potwierdzają prawdziwą ich wartość. Walidacja jest także niezbędna do zainteresowania sektora spożywczego korzystaniem z opracowanej bazy danych ProgBaz.

\section{Podsumowanie}

Funkcjonalność modeli opracowanych w ProgBaz polega przede wszystkim na dostarczaniu informacji o odpowiedzi wybranych mikroorganizmów na zadane czynniki środowiska. Parametrami opisującymi populację są: lag faza (czas przystosowania się populacji drobnoustrojów do zadanych warunków środowiska, a więc bezpieczeństwa produktu), tempo wzrostu w fazie wykładniczej oraz czas pomiędzy podziałami drobnoustrojów (informujące jak szybko populacja osiągnie wysoki poziom koncentracji). Są to informacje pozwalające oszacować bezpieczeństwo produktu oraz jego termin przydatności do spożycia. W tym kontekście ProgBaz może być wykorzystywana do oceny ryzyka mikrobiologicznego żywności, opracowania planów bezpieczeństwa żywności, do ograniczania marnotrawstwa żywności oraz projektowania nowych produktów. ProgBaz może stanowić także źródło informacji w opracowaniu planu zarządzania ryzykiem oraz stanowić narzędzie edukacyjne i szkoleniowe.

ProgBaz SGGW powstała w wyniku realizacji Programu "Inkubator Innowacyjności +" realizowanego w ramach projektu pozakonkursowego pn. "Wsparcie zarzadzania badaniami naukowymi $i$ komercjalizacja wyników prac $B+R w$ jednostkach naukowych $i$ przedsiębiorstwach" $w$ ramach Programu Operacyjnego Inteligentny Rozwój 2014-2020 (Działanie 4.4).

Umowa Nr MNISW/2017/DIR/36/II+ z dnia 07.03.2017. Decyzja nr11/II+/2017.

\section{Literatura}

[1] Brucker S., Albrecht A., Petersen B., Kreyenschmidt J.: A predictive shelf life model as a tool for the improvement of quality management in pork and poultry chains. Food Control, 2013, 29, 451460 . 
[2] Butler F., Xu Y.: Prediction of Staphylococcus aureus growth in ham during chilling using Pathogen Modeling Program. Biosystem Engineering, 2011, 16, 20-23.

[3] Devlieghere F., Francois K., Vermeulen A., Debevere J.: Predictive microbiology. In: Predictive Modeling and Risk Assessment. Integrating Safety and Environmental Knowledge into Food Studies towards European Sustainable Development. Ed. R. Costa, K. Kristbergsson. Springer, Boston 2009, pp. 29-53.

[4] Domańska S.: Weryfikacja modeli prognostycznych opracowanych dla produktów z mięsa wołowego rozdrobnionego. Praca magisterska, SGGW, Warszawa 2007.

[5] González S.C., Possas A., Carrasco E., Valero A., Bolívar A., Posada Izquierdo G.D., GarcíaGimeno R.M., Zurera G., Pérez-Rodríguez F.: MicroHibro': A software tool for predictive microbiology and microbial risk assessment in foods. Int. J. Food Microbiol., 2019, 290, 223-226.

[6] Huang L., Juneja V.K., Yan X.: Thermal inactivation of foodborne pathogens in the USA pathogen modeling program. J. Therm. Anals. Colorim., 2011, 106, 191-198.

[7] Huang L.: IPMP 2013 - A comprehensive data analysis tool for predictive microbiology. Int. J. Food Microbiol., 2014, 171, 100-107.

[8] Huang L.: IPMP Global Fit - A one-step direct data analysis tool for predictive microbiology. Int. J. Food Microbiol., 2017, 262, 38-48.

[9] Jałosińska-Pieńkowska M.: Prognozowanie bezpiecznego okresu trwałości modelowych wyrobów mięsnych gotowych do spożycia. Praca doktorska, SGGW, Warszawa 1999.

[10] Kajak K.: Prognostyczne modele trwałości mikrobiologicznej solonych i peklowanych produktów mięsnych. Praca doktorska, SGGW, Warszawa 2005.

[11] Karpińska M.: Weryfiakcja modeli prognostycznych opracowanych dla produktów z mięsa rozdrobnionego wołowego. Praca magisterska, SGGW, Warszawa 2007.

[12] Kopeć E.: Prognostyczne modele zmian mikrobiologicznych w produktach mięsnych. Praca doktorska, SGGW, Warszawa 2003.

[13] Koseki S.: Microbial responses viewer (MRV): A new ComBase-derived database of microbial responses to food environments. Int. J. Food Microbiol., 2009, 134, 75-82.

[14] Plaza-Rodríguez C., Thoens C., Falenski A., Weiser A.A., Appel B., Kaesbohrer A., Filter M.: A strategy to establish Food Safety Model Repositories. Int. J. Food Microbiol., 2015, 204, 81-90.

[15] Rosiak E., Kajak-Siemaszko K., Trząskowska M., Kołożyn-Krajewska D.: Prognozowanie w mikrobiologii żywności. Post. Microbiol., 2018, 57 (3), 229-243.

[16] Rozporządzenie Komisji (WE) nr 2073/2005 z dnia 15 listopada 2005 r. w sprawie kryteriów mikrobiologicznych dotyczących środków spożywczych. Dz. U. L 338, ss. 1-26, z 22.12.2005.

[17] Seliwiorstow T., Uyttendaele M., de Zutter L., Nauta M.: Application of TRiMiCri for the evaluation of risk based microbiological criteria for Campylobacter on broiler meat. Microb. Risk Anal., 2016, 2 (3), 78-82.

[18] Szczawiński J.: Mikrobiologia prognostyczna - zastosowanie praktyczne. Med. Weter., 2012, 68 (9), 540-543.

[19] Trząskowska M.: Prognostyczne modele wzrostu i przeżywalności bakterii probiotycznych w wybranych produktach żywnościowych. Praca doktorska, SGGW, Warszawa 2006.

[20] Zielińska D.: Prognostyczne modele przeżywalności bakterii probiotycznych $\mathrm{w}$ fermentowanym napoju sojowym. Praca doktorska, SGGW, Warszawa 2008. 


\title{
ESTIMATION OF GROWTH AND SURVIVAL OF PROBIOTIC, SPOILAGE AND PATHOGENIC BACTERIA IN FOOD USING PROGNOSTIC DATABASE (ProgBaz SGGW)
}

\author{
S u m m a r y
}

Predictive microbiology is based on the assumption of repeatability of the microbial population response to the given environmental factors of a food product. Based on empirical data from the microbiological experience, predictive models are developed as online available computer software.

The objective of the research study was to develop a database of predictive models of potentially probiotic, saprophytic and pathogenic bacteria in the form of a tool useful for the end customer and installed on the SGGW server under the name of "ProgBaz SGGW". The study material consisted of mathematical models of growth and survival of saprophytic bacteria (psychrotrophs, Pseudomonas spp., yeasts and moulds), pathogenic bacteria: Salmonella spp., S. aureus, L. monocytogenes (disadvantageous micro-flora) and potentially probiotic strains of Lactobacillus genus (advantageous micro-flora). The models were developed in the Department of Hygiene and Food Quality Management at the Faculty of Human Nutrition and Consumption Sciences at the Warsaw University of Life Sciences in 1997 - 2008.

ProgBaz is available on the main website of SGGW (Warsaw University of Life Sciences referred to as SGGW) in Warsaw, Economy tab and on the website of the Faculty of Human Nutrition and Consumer Sciences, SGGW, Science and Services tab. The user can estimate the growth or survival of microorganisms over time and affected by environmental factors (temperature, $\mathrm{NaCl}$ level, $\mathrm{NaNO}_{2}$ level, and inulin additive) in the following products: model product made of minced meat, in dairy, meat and vegetable marketable products. In addition, it is possible to acquire information on the characteristics of the population $(\lambda, \mu, \mathrm{GT}, \mathrm{N})$ and the quality of predictive value in the case of a validated model. This is the information that makes it possible to estimate the safety of the product and its shelf life. ProgBaz can be used to assess the microbiological risk of food, to develop food safety plans, to reduce food waste, to design new products, and to provide an educational and training tool.

Key words: food, predictive microbiology, predictive models, predictive database, ProgBaz 